\title{
Decrease of Fertility without Increase in Contraceptive Use: Interrelationship between Migration and Fertility Behavior in Himali Gaunpalika in Nepal
}

\author{
Bishnu Prasad Dahal \\ Department of Anthropology, Patan Multiple Campus, Patan Dhoka, Tribhuvan University, Kathmandu, Nepal \\ Email: phd.bishnudahal@gmail.com
}

How to cite this paper: Dahal, B. P. (2020). Decrease of Fertility without Increase in Contraceptive Use: Interrelationship between Migration and Fertility Behavior in Himali Gaunpalika in Nepal. Open Journal of Social Sciences, 8, 114-140. https://doi.org/10.4236/jss.2020.85008

Received: April 1, 2020

Accepted: May 10, 2020

Published: May 13, 2020

Copyright ( 2020 by author(s) and Scientific Research Publishing Inc. This work is licensed under the Creative Commons Attribution International License (CC BY 4.0).

http://creativecommons.org/licenses/by/4.0/

\begin{abstract}
Migration from Nepal to other countries over the last 200 years includes pilgrims, devotees, political refugees, and soldiers. Throughout the twentieth and 20 years of the twenty-first century, Nepal has increased its role as a major labour-exporting country and mostly economy depends on remittance. This research paper explores the new trends of fertility and tendencies of contraceptive are in relation to migration especially male, ecology and population dynamics. Use of contraceptive is not usually determined by the use of contraceptive in case of human in general but in some cases, fertility is a complex whole which can be determined by multiple factors like ecology, religion, culture, social dynamics, demographic dynamics etc. The objective of this paper was to identify the situation of migration trends in relation to fertility in the study area. Fertility mainly depends on male migration towards abroad and even in India, geography, climate (cold climate), heavy work load due to difficult geography, food habit (mainly carbohydrate sufficiency rather than protein based) etc. are playing a key role for decreasing fertility rather than using contraceptives in case of Himali Gaupalika of Bajura district of Nepal.
\end{abstract}

\section{Keywords}

Migration, Fertility, Contraceptives, Male Migration

\section{Introduction}

Demography anthropology is relatively a new sub-division in anthropology. Demographic anthropologists concern about adaptation. Elsewhere in the world, anthropologists have shown this serious concern in understanding the long-term 
history of population dynamics and demographic processes in primitive and peasant societies. Not only anthropologists have researched about the population dynamics but, demographers, such as Caldwell and others have shown great interest in anthropological approaches to demographic research (Caldwell, 1976). Caldwell and his elaborators have used the "participant observation methods, the quasi-anthropological techniques" in their terms into their demographic research in Nigeria and India. Caldwell's theory of internal "national wealth flows (1971)" has systematically placed family, culture and social organization together to understand the processes of demographic transition (Caldwell, 1976).

Many classical anthropologists consider, populations are the variable and as one of the causal factors of human culture. This model viewed fertility, as a part of the cause of marital relationship and a part of the functionalist tradition. Anthropological demography began to expand in earlier only after 1970 with the convergence of these trends. One of these was the growth of methodological sophistications motivated by the needs of physical anthropology and archaeology. The study of Nancy Howell's work in addition to supporting the possibility of demographic fieldwork also contributed to the new methods of fieldwork for data collection (Howell, 2000). The second trend, criticizes the family planning programs and it challenges the assumptions of classical demographic transition theory by showing that colonial contact and capitalization of indigenous population can actually accelerate population growth by increasing the demand for children (Caldwell, 1976). Another, but most one is the third trend, in which ecological anthropology possessed a long standing interest in population activated with these other developments. Ecological analysis has always focused on subsistence behavior within and environmental context and demographic variables were always seen as a part of the relationship. Here, I agreed with Stewardian ecological analysis that, it is needed to determine how much exploitative behavior influenced other aspects of culture, including demography, settlement patterns, ownership structures, land tenure and land use.

Modern cultural ecology is different from classical cultural ecology not only in terminology but also in perspectives. Modern ecological analysis is a return and advance from previous neo-functionalist and neo-evolutionist schools represented by Rappaport, Steward and White, although it incorporates many of the same issues of human and environmental interaction. Parallel with Orlove,

"Jahan pani alu paincha, Nepali paincha"

(where there are potatoes, there are Nepalese)

This saying is now truer than ever. Permanent migrations from hill to the Tarai and from rural to urban areas have constantly been on the rise since the 1970s due to the Malaria eradication, expansion of cities in the Tarai and searching for opportunities and services available there are the main causes along with. In 2009, every day 700 to 800 while it is increased from 1000 to 1100 by 2018 (DoFE, 2018), Nepalese workers headed for foreign countries, other 
than India. Even though, it is impossible to find out exactly, how many Nepalese workers work abroad? It is estimated that 4 to 6.5 million people working permanently or temporarily outside the country (Thieme, 2006).

\subsection{Migration}

Emigration refers to leaving one's native country intending to settle temporarily or permanently in other countries. The process of shifting from country or society to another is a migration. It is estimated that three million Nepali (productive age group; ranged from 20 years to 40 years) are abroad as migrant workers for earning money. The nation, with 26.4 million populations (more than 10 percent of productive age group people) has migrated to search opportunity to work abroad (except India), halting its own country's development (DoFE, 2014). It is assumed that, around 3 million people working in India, since Nepali do not need visa and work-permit for Indian job market, it is hard to find out the exact number of those people for this trend dates back to centuries. According to the official data of Department of Foreign Employment (DoFE, 2014) a significant number of the Nepali migrant workers are engaged in 3D works (Difficult, Dirty, Dangerous) in various countries, from Qatar to Malaysia and from South Korea to Israel. However, a negligible portion of this work force has also been engaged in managerial or some kind of "decent" jobs in the host countries.

The number of Nepali workers leaving home for foreign employment is increasing day by day. An official figure shows that a total of 527,814 Nepali men and women left the country in the fiscal year 2013-2014 (DoFE, 2014). In addition, the data maintained by DoFE does not include records of individuals who leave the country for foreign employment illegally via India or with support of middlemen. It supports to make obvious claim that the number of emigrants is more than official data published by Government of Nepal.

Globalization ultimately impacts Nepal by globalization of manpower as new mobility paradigms, since the first Gurkha recruitments at the beginning of the nineteenth century. However, as Skeldon (2008) emphasizes the scale of international migration must not conceal the importance of internal movements and research conducted by Hollema et al. (2008), give a complete overview of migration, from forced to labor or study migration, at both internal and international level. In another hand, Sinha (2009) associates the study of Nepalis of Indian origin with that of Indians of Nepali origin, and considers the many points they have in common to be worth studying together. Now Nepal is good remittance earning nation as main sources of economy (CBS, 2004).

Massey et al. (1993) studied the culture of migration as a promising field of research and found out the "push and pull" factors or other theories to explain migration. Adhikari and Seddon (2002) focus on some Lahure songs and writings from Pokhara, which are part of a culture of migration defined as "those ideas, practices and cultural artifacts that reinforce the celebration of migration 
and migrants" (Ali, 2007).

Studied about Migration was paid attention for a decade within the migration as the determining factor of development (Taylor, 2006) but later, discourse shifted towards main economic base for national budget through remittances as an example or role model for the world (Khanal \& Watanabe, 2006). Studies should be favored in order to understand how migration affects social transformations among migrant and non-migrant households, but also how development itself leads to further migrations (Bohra \& Massey, 2009; Webber et al., 2012). Adopting the hypothesis that migration is one of the factors that changes Nepalese society, the role of economic and social remittances (Levitt, 1998).

Although Nepal has improved across many reproductive health indicators, challenges remain. Since 2006, the contraceptive prevalence rate (CPR) has stagnated ( $48 \%$ vs $53 \%$ in 2016), while traditional method use has more than doubled in the same time period (NDHS, 2011). Use of modern family planning is nearly three times higher among married women who live with their husbands (68\%) than those who do not (24\%) (NDHS, 2011). The rate of family planning discontinuation has become a major concern for the government of Nepal. NDHS (2016) identified the association between husbands moving away from their homes (for any purpose) as the primary reason for discontinuation of family planning, followed by side effects, and desire to become pregnant. The Nepal Family Health Program survey also showed that women with migrant husbands tend to discontinue family planning methods when separated from their spouses to avoid rumors about infidelity from in-laws and community members (NFHP II, 2012).

Globally, studies have identified health disparities among women with migrant husbands (Chen et al., 2015) and negative consequences of migration on other family members' health (Gao et al., 2010), children's education (Morooka \& Liang, 2009) and child wellbeing (Schmeer, 2009), Mental health issues have also been identified among wives of migrant husbands, including increased feelings of loneliness and isolation (Skledon, 2009) and depressive symptoms (Lu, 2012). In India, women with migrant husbands have higher levels of reproductive morbidity (Roy \& Nangia, 2005) and sexually transmitted infections than women married to non-migrants (Sevoyan \& Agadjanian, 2010).

This is further complicated by limited access to sexual and reproductive health services for wives left behind (Seddon et al., 2001). Positive impacts of husbands' migration include increased accrual of money and material items and improvement in women's decision-making power, particularly for the management of resources and household affairs (Kaspar, 2006).

The sons are very highly prized and daughters are desired because sons continue the family name, continue their lineage, transfer of parental properties in lineage system, can perform funeral rituals are and expected to provide support in old age. This patrilineal social structure discourages women from practicing contraception until they have a son (Karki, 1992). The son preference may exert 
an influence not only on contraceptive use and fertility levels, but also on the progress of fertility decline.

\subsection{Focus of the Research}

This research is mainly focusing on the searching the answers of these questions as: is migration a key strategy for managing livelihoods in a socioeconomically, environmentally, and politically fragile context in Himali Gaunpalika of Bajura district? Is decrease of fertility directly related with migration of male among couple in study area of any other factors are responsible for such a situation? Male migration from country to overseas and in India be increasing in one hand and import of contraceptive means are also increasing day by day in country, actually what plays the key role in controlling or decreasing fertility rate migration or contraceptives? These are the questions and searching the answers of these questions ultimately provides the outline of the research theme.

Theoretically, in Himali Gaupalika is one in which many anthropologists' and demographers' idea can be juxtaposed while describing the soci0natural system through cultural ecological perspective of Julian Steward based on John Bennets' theory (of cultural ecology, sub-discipline-population ecology).

Theoretically, I adopt the Stewardian model of cultural ecology and ecosystem based model propounded by Andrew Vadya and Ray Rappaport on the study of socio-natural system of Himali Gaupalika as Tsembaga community. In this paper I want to propose such theoretical stand on the economic strategy according to their ecological settings. The general objectives of the article are:

- To describe a subsistence economy and to determine what constraints or limiting factors operate in that socio-natural system through ecological-anthropological model/ perspective?

- To examine the interrelation of environment and economy through ecological model from an anthropological perspective.

- To examine the decrease of fertility in terms of soil fertility and human fertility without increasing contraceptives.

- To examine the trends of migration in Himali Gaupalika.

According to anthropological ecology, subsistence economy of Himali Gupalika includes:

1) Elements of the physical environment (abiotic) such as climate, soil, water

2) Elements of the biological environment (biotic) such as plants, vegetation, forest, flora, fauna

3) Elements of culture (anthropic) such as local technology, cultural attitudes and beliefs and social organization, and

4) External environment that infringe on or are exploited by the society (institutional) such as government structures, outside markets, outside traders and outside employment opportunities (migration).

A subsistence economy of flow of inputs and outputs found more or less equal 
in Himali Gaupalika. Meeting the subsistence demands and social religious requirements (life cycle, rites, festivals, ritual ceremonies, exorcism) using their own modes and means is the condition of subsistence. For this equilibrium condition, the inputs of the system are human and animal labor and existing physical and biological resources where as the outputs are production of goods (animals, cottage industry, and agriculture products), labor outside the

The specific objectives of this paper is to identify the proportion of women with migrating husbands and describe the understudied implications of male-partner migration on family planning and related reproductive health factors. It is examined that; Why has fertility in Nepal recently decreased without a corresponding increase in contraceptive use? This paper describes the male migration is an important factor, both for fertility decline and for non-use of contraceptives. Among samples of young women (20 - 40 years) with migrant husbands from Himali Gaupalika and assesses selected contraceptive prevalence among the women whose husbands are present in the home.

\section{Theoretical Overview}

Ecology is also another alternative perspective to analyze the human behavior especially fertility behavior in a wider sense. Ecology acts as a major component of variations; either genetic variation (either by geographical isolation, or by adaptation of species or by origin of new species) or cultural variations. In this context there is interplay between nature and nurture i.e. biology vs sociology in terms of studying human behavior via fertility. Here, nature vs. nurture debate is one of the most common while studying the fertility behavior. "Nature" refers to biological/genetic predispositions' impact on human traits, and "nurture" describes the influence of learning and other influences from one's environment. The debate over whether the strengths and weaknesses of people are the result of nature or nurture has, and somewhat continues to rage on between scholars and lay people alike. This debate has had significant social implications, particularly concerning what are thought to determine people's ability to learn/intelligence.

Fertility behavior should be studied by using system based approach or ecosystem based model because fertility of animal (both human and non-human) depends on their ecology or environment (both abiotic-climate, geography, topography, available of resources etc. and biotic-living palnts etc.) through the energy flow and carrying capacity. Ecologigal anthropologists, Lesle A. White, Julian Steward, Roy Rappaport and Andrew Vadya all focused upon the how environment shape the human life especially population regarding fertility in adaptation with their environment both-social and natural. These methods rely on the usage of measurements such as caloric expenditure and protein consumption. Careful attention was given to concepts derived from biological ecology, such as carrying capacity, limiting factors, homeostasis, and adaptation. This ecosystem approach remained popular among ecological anthropologists during the 1960s and the 1970s (Milton, 1997). 
Many classical anthropologists consider, populations are the variable and as one of the causal factors of human culture. This model viewed the fertility, as a part of the cause of marital relationship and was a part of the functionalist tradition. Anthropological demography began to expand in earlier only after 1970 with the convergence of these trends (Fricke, 1986). The trend, criticizes the family planning programs and it challenges the assumptions of classical demographic transition theory by showing that colonial contact and capitalization of indigenous population can actually accelerate population growth by increasing the demand for children (Fricke, 1986). Another, but most one is the ecological anthropology possessed a long standing interest in population that activated with these other developments. Ecological analysis has always focused on subsistence behavior within and environmental context and demographic variables were always seen as a part of the relationship. Fricke agrees with Stewardian ecological analysis that, needed to determine how much exploitative behavior influenced other aspects of culture, including demography, settlement patterns, ownership structures, land tenure and land use. Fricke also applied the Boserupian model, as population growth gave rise to agricultural intensification. Agrees with Steward and Boserup, Fricke mentions the role of population variable in social change. He also adopts the Caldwellian model in which Caldwell argues the population transitions depend on the socio-culture matrix of fertility behavior (Fricke, 1986). His population analysis based on ecological tradition paid attention on many theoretical as well as practical grounds.

Modern cultural ecology is different from the classical cultural ecology not only in terminology but also in perspectives. Modern ecological analysis is a return and advance from previous neo-functionalist and neo-evolutionist schools represented by Rappaport, Steward and White, although it incorporates many of the same issue of human and environmental interaction. Parallel with Orlove, Fricke believes on that Timling adaptation cannot be taken to imply long-term equilibrium. Since that, would employ either no limit to the resources on which the population depends on the steady state model in which no system grows at the expense of another. Since, population is increasing with obvious consequences for traditional production; the focus must be on change. Fricke focuses on the perspectives of the actions themselves, while the changes that occur on the result of these entirely rational courses of action.

According to Fricke, the Timiling population's adaptation is mainly based on the Timiling environments. The dialectical, causal relation between mountain environment and Timiling adaptation is viewed by the Fricke through the various general things of social change (Fricke, 1986). Fricke further believes that, from the ecological perspective, the primitive analytic concerns in the process of procuring a living in the local environment. Demographic process becomes important in this analysis to the recent that constraints and offer opportunities of people in search of their livelihood. According to Fricke, Timiling lies people at an extremely rugged corner of the Himalayan and holds, a number of traits in 
common with mountain population throughout the world. In such kind of environmental situation, the range of solutions of the livelihood problem or adaptation problem is relatively harsh compared to that of more generous environments that's why, Fricke's (follower of Steward) analysis will be must successful so as to identify the primary subsistence pattern determining the other components of culture.

\section{Methodology}

Methodologically, this study followed the explorative, descriptive and analytical research design. Information about socio-economic features, geographic features, economic features cultural features were gathered by using explorative and it was described according to the informations explored in study area. Fertility decrease, trends of migrations, use of contraceptive trends and tendecies including more information were gathered by using different tools and techniques were analyzed by using analytical research design.

\section{Study Design and Sampling}

This research was conducted in Himali Gaupalika from August and September, 2019.

During the course of study, both quantitative and qualitative data were collected, open ended interview, structured interview and semi-structured interviews were carried out among total 210 respondents each 30 from 7 wards. The respondents were selected on the basis of the criteria that whose husbands were not in their home, either respondent's husband were migrated in abroad, in gulf countries, India as foreign employee and or in many cities of Nepal as domestic employee. This information on maintaining confidentiality was provided to the participants both orally as well as through the information sheet. I have preserved the identity of each respondents and their settlement by using pseudonyms.

The primary objective of the study was to provide assessment and find out the correlation between and among fertility decrease and other various factors predominantly migration rather than contraceptives availability.

Himali Gaunpalika of Bajura district is newly named by merging the former three village development committees after local level units restructuring program of the Government of Nepal. Former three VDCs namely Bichchhya, Rugin and Bandhu in B. S. 2073 (2016 A.D.) were integrated by the government to make a larger unit than previous as Himali Gaunpalika with the parts of Bichchhaya, Rugin and Bandhu VDCs. Among them, previous Rugin and Bandhu VDCs are divided into each two wards of Himali Gaunpalika but previous Bichchhaya VDC is divided into three wards Himali Gaunpalika. The total area of this Himali Gaunpalika is $830.34 \mathrm{sq} \cdot \mathrm{km}$. It is the largest Gaunpalika of the entire Gaunpalika and Nagarpalika of Bajura district.

Three clusters of Himali Gaunpalika, Bichchhaya, Rugin and Bandhu were 
selected as the clusters tended to have a higher rate of male migration but having female contraceptive users especially temporary means of contraceptives.

Women self-reported as married. Women with migrating husbands were defined as having a husband who travels outside of the country for work for more than six months at a time. Across the variety of migration definitions, we focused on the wives of international migrants, as remittances from abroad provide some families with significant income, and the impact of those monies on factors associated with reproductive health has received limited attention in the literature.

\section{Findings}

From field work in Himali Gaupalika it was examined that their life adaptation in terms of

- The Subsistence Pattern

- The Social Demography

- Cultural and Individual Interface

However, mountain adaptation of Himali Gaupalika is influenced by various factors; here it was better to analyze the migration culture through broad or comprehensive perspective. By this way, I would like to synthesize the perspectives of land tenure ships, plus, population ecological perspectives and the perspectives of social, cultural or socio-natural system. This study, seeks to incorporate all of these issues into a single look at Himali Gaupalikas' adaptations through the interaction of population, social organization, and the economic activities.

\subsection{The Natural Resources Availability and Management}

Nepal occupies about $800 \mathrm{~km}$ of the central sector of the Himalayan arc. From south to north, Nepal can be divided into eight east-west trending physiographic zones namely: Terai, Siwalik range, Dun valley, Mahabharat Range, the Midlands, Fore Himalaya, Higher Himalaya and Inner and Trans Himalaya valley (Hagen \& Kizaki, 1994). Each of the above zones has different altitude, topography, climate, soil type, and geology and vegetation characteristics.

The district covers an area of $2188 \mathrm{~km}^{2}$ of Nepal. The district has four Nagarpalika and 5 Gaunpalika, among them Himali Gaujpalika is one. The district is situated in Longitude between $81^{\circ} 10^{\prime} 20^{\prime \prime}$ to $81^{\circ} 48^{\prime} 27^{\prime \prime}$ East and Latitude $29^{\circ} 16^{\prime} 21^{\prime \prime}$ to $29^{\circ} 56^{\prime} 56^{\prime \prime}$ north.

Geographically the district is divided in three distinct regions from north to south viz. Higher Himalayan Region, Higher Mountain and mid-Mountains. The Higher Himalayan region comprises Saipal Himalayan range; High Mountain region comprises Doha Lekh and Ghori Lekh. Similarly, Mid-Mountain range comprises different ranges of mountains e.g. Badimalika Temple. The District has started from $300 \mathrm{~m}$ to $6400 \mathrm{~m}$ in height. The annual rainfall is about 
$13,433 \mathrm{~mm}$ and temperatures vary from $0^{\circ} \mathrm{C}$ to $40^{\circ} \mathrm{C}$.

Livestock and agriculture is the predominant economic activity of the people of Himali Gaupalika of Bajura District. Out of the total geographical area $(83,030$ ha) of the Municipality, 2.62 percent of the area (2685 ha) is cultivated. Out of total cultivated land, the proportion of lowland and highland is 5.4 and 94.6 percent i.e. (145 ha) and (2540 ha) respectively. All the areas of low land are irrigated. Year round irrigated area is 80 ha and monsoon irrigated area is 65 ha. Thus, agriculture of large portion (2540 ha) of municipality cultivated area depends on seasonal rain. Wheat, paddy, maize, millet, barley, buckwheat are the main cereal crops grown in the municipality Some traditional minor cereals like common millet, Italian millet, naked barley, amaranthus (Latte) are also grown. But their individual area is minimal. The farmers of this area grow beans as major pulse. Other pulses soya bean, black gram, horse gram, small pea, lentil are also grown. Rapeseed, groundnut and spice crops are considered as high value crops. Potato and varieties of seasonal and off-season vegetables are produced. Likewise, major fruits apple orange, walnut and olive are grown in this municipality.

Wheat is the main cereal grown in this municipality. The average yield of wheat is $1.52 \mathrm{MT} / \mathrm{ha}$. The area under wheat is 871 ha and the production is 450 MT. Paddy is another food crop grown in the Himali Gaupalika. Paddy is grown twice a year in irrigated areas while it is grown once in the rain-fed areas. Monsoon paddy is the main paddy. The yield of paddy significantly varies by region and season depending on the irrigation and nutrient condition of the field. The area under monsoon paddy is 601 ha. The production of monsoon paddy is 1324 MT. The average productivity of monsoon paddy is $1.90 \mathrm{MT} / \mathrm{ha}$.

Maize is the main crop of Himali Gaupalika. The monsoon crop is the main maize crop. The area under monsoon maize is 283 ha. The production of monsoon maize is $425 \mathrm{MT}$. The productivity of maize is $1.50 \mathrm{MT} / \mathrm{ha}$. Different types of millets are grown here. Millet covers the area 446 ha and the production is also 446 MT. The yield per ha of millet is $1.00 \mathrm{MT}$ (Table 1).

It is found that, though there are various productions in Himali Gaupalika, it is insufficient for them, the major problem here found that most of the land were found uncultivable, the majority of populations were found migrated for opportunities in Kathmandu, Dhangadi, Gaddachauki and even in Banbasa. Some of them have gone to India, and rest were in gulf countries and very few for abroad.

\subsubsection{Flora and Fauna in Himali Gaupalika}

Cattle, buffalo, goat and pig are the major animals reared in Himali Gaupalika. The total number of cattle is 7341. Similarly, the total number of buffalo is 1162 . The proportion of cattle is high as compared to buffalo. The number of $\mathrm{yak} / \mathrm{nak} / \mathrm{chaury}$ is 56 . Table 2 depicts the distribution of reared animals in the municipality. 
Table 1. Area, production and yield of food crops in Himali Gaupalika, Bajura.

\begin{tabular}{cccc}
\hline Food Crops & Area (ha) & Production (MT) & Yield (MT/ha) \\
\hline Cereals & & & \\
Wheat & 871 & 1324 & 1.52 \\
Monsoon paddy & 601 & 1142 & 1.90 \\
Millet & 446 & 446 & 1.00 \\
Monsoon maize & 283 & 425 & 1.50 \\
Barley & 130 & 130 & 1.00 \\
Buckwheat (Phaphar) & 19 & 15 & 0.80 \\
Common millet (Chino) & 7.07 & 6.01 & 0.85 \\
Italian millet (Kaguno) & 5.40 & 3.78 & 0.70 \\
Naked barley (Uwa) & 4.16 & 2.50 & 0.60 \\
Pulses & & & \\
Beans & 44 & 42 & 0.95 \\
Soya bean & 26 & 21 & 0.80 \\
Lentil & 13 & 6 & 0.46 \\
Black gram & 12 & 10 & 0.75 \\
Pea small & 13 & 20 & 1.50 \\
Horse gram & 15 & 8. & 0.55 \\
\hline
\end{tabular}

Source: Field survey, 2019.

Table 2. Numbers of animals reared in Himali Gaupalika, Bajura.

\begin{tabular}{cccccc}
\hline S.N. & Animals & $\begin{array}{c}\text { Bijchhya } \\
\text { Wards 1, 2, 3 }\end{array}$ & $\begin{array}{c}\text { Bandhu } \\
\text { Wards 6, 7 }\end{array}$ & $\begin{array}{c}\text { Rugin } \\
\text { Wards 4, 5 }\end{array}$ & $\begin{array}{c}\text { Total } \\
\text { Wards 1 - 7 }\end{array}$ \\
\hline 1 & Cattle & 1914 & 2917 & 2510 & 7341 \\
2 & Buffalo & 350 & 405 & 407 & 1162 \\
3 & Yak/Nak/Chauri & 55 & - & 1 & 56 \\
4 & Sheep & 2398 & 198 & 842 & 3438 \\
5 & Goats & 2804 & 2481 & 3619 & 8904 \\
6 & Pig & - & 8 & 47 & 55 \\
\hline
\end{tabular}

Source: Field survey, 2019.

\subsubsection{Sheep and Goat Farming}

The total number of sheep is 3438 and the total number of goats is 8904 . Mostly local sheep and goat is here. Farmers bring fodder leaves from nearby forest. Fodder leaves and grass are hanged in the sheep goat shed. In practice three times feeding to goat are being done. Salt is mixed in water and given to the goat. Farmers sell their sheep goats during festival days. In festival days farmers receive higher price for their sheep goat.

\subsubsection{Forest and Biodiversity}

This municipality has community forests, leasehold forests and government forests. There is no private, collaborative, reserve and religious forests. The total number of community forest and leasehold forests are 29 and 18 respectively. The area of community forest is 3079.5 ha and of leased hold forest 276.2 ha. The location of community forest is spread in ward numbers 1 to 7 while leased hold forest in 6 and 7 only. 
Major species are Khote sallo, Lauth sallo,, Lekhe sallo, Pangar, Kaulo, Kharsu, Banjh, Laligurans etc and in leased hold forest Amrisho, Bans, Kurilo Timur, Sugandhwal chiraito, Lokta, Guchi chyau. Cover type in all the community forest and govt. forest is Conifer, Broad leaved, Mixed, Bushes. Climatic zone varies from Sub-tropical to Tundra. Forest condition is good with natural regeneration sufficient. The maturity class of Community forest is immature to mature while crown density in most community forest and govt. forest is $40 \%$ to $70 \%$ and in some areas it is more than $70 \%$ also. The altitudinal variation is very high 6924 $\mathrm{m}$ in Himali Gaupalika.

Different types of forests are found which are classified as Sub tropical, Lower temperate, Upper temperate, Upper temperate mixed Broad leaved, Sub alpine, Alpine and Tundra forests in the altitudinal range of 1000 meter to $4500 \mathrm{~m}$ from sea level. Himali Gaupalika has pure stand of Pinus roxburghii forest (1120 m $2222 \mathrm{~m}$ ) generally in south or south-western aspects, at lower altitude. Alnus nepalensis pure forests in subtropical forest type is found at wet riverain topography, in wet gullies and soil exposed due to landslides in the form of colonizer while Quercus leucotrichophora forest (1750 - $2336 \mathrm{~m}$ ) found often in all aspects yet at lower altitude generally in the eastern aspect, Quercus floribunda forest $(2100-2800 \mathrm{~m})$ per species as an associate. Pinus wallichiana forests $(1810-2100 \mathrm{~m})$ in lower temperate forest zone in three municipalities found as a pure stand generally in the northern, western and west north aspect but sometimes at higher altitude mixed with $Q$. semicarpifolia. On the other hand, Upper temperate forest has Quercus semicarpifolia (2600 - $3700 \mathrm{~m}$ ), Mixed Broad leaved forest $(2400-3150 \mathrm{~m})$ in north and west facing slopes with Rhododendron, Acer spps A. pictinatum, Juglans regia, kaulo, Aesculus indica and in understorey Nigalo, Rhododendron, Coniferous forests up to $4000 \mathrm{~m}$ Pinus wallichiana and associate species Abies pindrow, Picea smithiana, Tsuga demosa, Taxus baccata in southern and or northwest aspects in all three municipalities. Sub-alpine forest (above $3300 \mathrm{~m}$ ) has pure stand of Betula utilis forest with under storey Rhododendron, Acer spp, Q. semicarpifolia and Rhododendron forest in all municipalities in wet and moist sites. Alpine forest in Budhinanda municipality above $4200 \mathrm{~m}$ especially shrubbies. Rhododendron species are found in moist/wet sites. Tundra type vegetation up to $4500 \mathrm{~m}$ Thorney shrubs, and grasses etc are found in Himali Gaupalika.

Verities of flora and fauna species were found in Himali Gaupalika, within small geography. The diversity of the flora and fauna found in study area indicated that there are so many opportunities to produce and commercially farming of it, but lack of focus, investment and lack of appropriate technologies hindered the development of such flora and fauna based farming. For, this in tendency of mal development, one of the major key factors is, human resources. Usually, people do not want to stay in village for their own work as entrepreneur, rather they want to migrate to cities for small clerical job to satisfy their mere subsistence. That's why the decrease soil ferity by uncultivable of their land in one 
hand because of lacks of human resources ultimately impacts on their human fertility, without using contraceptives.

\subsubsection{Climate and Temperature}

Climate is one of the important factors for Soil formation. Temperature and precipitation of the survey area influenced the soil formation. Directly it affects by supplying water and heat to react with parent material whereas indirectly it determines flora and fauna activities which furnish a source of energy in the formation of organic matter. This energy acts on the rocks and as a result minerals in the form of acids and salts are released (Stöcklin, 1980).

Climatic conditions of Nepal vary from one place to another in accordance with the geographical features in which topography and altitude are the major determinants. Broadly, in north, summer is cool and winter is severe, while in south summer is tropical and winter is mild. Bajura district lies in the hilly region of Nepal and has climatic sub-tropical climate. Long-term (2006 to 2016) temperature and rainfall data were collected from nearby station which is the representative station of climate in the project area.

Temperature data analysis showed that the area is under subtropical region. The data showed that the Pre-monsoon season (April-May) that corresponds to the summer naturally has the highest mean maximum temperature $\left(26.02^{\circ} \mathrm{C}\right)$ in the month of August and mean minimum temperature is $2.41^{\circ} \mathrm{C}$ in the months of January.

The vary temperature and climate indicated that, there are hardship of life. Most of the lands are highland and few lands are lowlands. In highland, with high altitude harvesting period is higher than that in low land. It directly impact on ferity of land and human. Here, I would like to mention the concepts of Stewardian ecological analysis that, needed to determine how much exploitative behavior influenced other aspects of culture, including demography, settlement patterns, ownership structures, land tenure and land use. In my opinion, it is appropriate to juxtaposed the settlement pattern of Himali Gaupalika with the settlement pattern that was found in Boserupian model, as population growth gave rise to agricultural intensification. Agrees with Steward and Boserup, but lacks of human resources for both agricultural intensification and population growth i.e. fertility,

It was found from the Himali Gaupalika that the adaptation depended on their,

- Simple social organizations and substance economy

- Peasant society dominated by agro-pastoral characteristics

- To cope with newly created environment with surroundings

- Natural resources: land, forest, pasture, arable land

\subsection{Demographic and Social Settings}

Fertility, mortality and migrations are the common area of interest for any demographic anthropologist. Among those, fertility in the one which can deter- 
mine the nature and characteristics of populations, though Himali Gaupalika people don't use any means of contraceptive devices, the fertility rate becomes very low. In other words, the rate of fertility determines the community adaptation to its environment.

The social settings include the population distribution and density pattern, age composition, caste/ethnicity and religious composition and literacy status, which is discussed in the following sections.

The Gaunplaika is diverse society in terms of caste, and physical settings. Hill Brahmin, Chhetri and Hill Dalit are major group are inhabited in the Gaunpalika. Hill Brahmin, Chhetri are the predominant group in the Gaunpalika. They perform unique local feast and festivals such as Bhuwo, Kulo Sorai, Ladi Tanai, Khauu.

The distribution pattern of settlement area is heterogeneous, in market area the settlement area is clumped and on rest area it is distributed in scatter form. Most of the settlements areas are located along the riverbanks, flat land of low area, adjoining to the roads site and at main bazaar. The main market area of this Gaunpalika lies on ward number 6. Since, in the Gaunpalika, some of the area lies on alpine zone, seasonal and permanent migration can be seen towards the low land. People in this area use public tap and spring for drinking water. In all wards, almost all of the houses have toilet facilities. The sanitation problem in this Gaunpalika is bad, many of the people suffered from water borne disease and reason for the death of the people. Similarly, sanitation, solid waste management, drainage system etc are also another environmental problem causing water borne disease. Road side settlement areas are suffered both air and noise pollution causing long term diseases like asthma, cancer, loss of hearing etc. Regarding energy use, most people of main market area use both LPG gases and fire wood for cooking purpose, beside this most people from the rest ward uses fire wood for cooking purpose which are the main cause for indoor air pollution. The people with asthma disease in the area are very much and it is because of smoking, indoor air pollution etc. Regarding road, the construction of rural and district road is going on, In spite of this, from 4, 6 and 7, Karnali corridor passes through these wards. Along with this, some of the settlement areas are located at hazard prone area. Drought, landslide, flood, Hailstorm and epidemic disease etc. are the main natural hazard are frequently occurring in this region. Because of this, many people in all wards died with huge economic losses each year. On the year 2075, there was huge landslide at ward number 1 affecting 3 families with huge economic lose i.e. nearly 3 lakhs. The people of Bichchhaya Tallobasti, Faitai Gaun and Bodik Gaun of ward number 1, 4 and 6 respectively are living in landslide prone area. Proper action must be taken in time to minimize human and economic losses.

\subsubsection{Demographic Settings}

According to Himali Gaunpalika Bastugat Bibaran (2075), the total population of Himali Gaunpalika is 11,253 . Out of the total population, 52.49 percent are 
male and 47.51 percent are female. Table 3 shows the ward wise distribution of population by sex.

Table 3 shows that ward number 6 has the largest population size as compared to other wards, which occupies 29.85 percent of the total population of the Gaunpalika. Ward number 3 has the smallest size of the population, which is 8.66 percent. Sex ratio of the Gaunpalika is 110.06 , which is higher than national sex ratio (94.2). Sex ratio of ward no. 2 is 122.36 , which is the highest of all wards. Sex ratio of ward no. 3 is 93.64, which is the lowest of all wards. Obviously, sex ratio is the high of all wards except ward number 3 . Its average household size is 6.01 , which is higher than the national average (4.88). Household size ranges from 5.60 in ward no. 6 to 7.08 in ward no. 4 .

The population growth rate of Himali Gaunpalika is $3.16 \%$ per year. According Bajura Jillako Bastugat Bibaran 2074 shows that, the population of Himali Gaunpalika was 9214 and Himali Gaunpalika Bastugat Bibaran, 2075 estimates that the total population of Himali Gaunpalika is 11,253 . The population of Himali Gaunpalika is 11,253 (Himali, 2019) which has been projected to be 12,941 in B.S. 2080 with population growth rate of $+3.16 \%$ per year. Considering the same growth rate of population per year i.e. $+3.16 \%$ per year, the projected population for 2085 will be 14,628 . Overall population density of the Gaunpalika is 39.14 persons $/ \mathrm{km}^{2}$, which is lower than the average national density (190.63 persons $\left./ \mathrm{km}^{2}\right)$.

According to CBS (2011) presented in Table 4, ward no. 6 has the highest population density of 631 person per sq. $\mathrm{km}$ and ward no. 3 has the lowest population density of 2.00 person per sq. $\mathrm{km}$. Ward no. 4 has the second largest population density of 68.98 person per sq. $\mathrm{km}$. and ward no. 1 has the second lowest population density of 9.01 per sq. $\mathrm{km}$.

Proportion of people at different age groups determines whether population of a particular area is young or old, or getting older or younger. Age wise population distributions of the Gaunpalika are as follows Table 5.

Table 3. Ward wise population distribution by sex in Himali Gaunpalika.

\begin{tabular}{ccccccccc}
\hline \multirow{2}{*}{$\begin{array}{c}\text { Nard } \\
\text { No. }\end{array}$} & \multicolumn{9}{c}{ Male } & Percent & Female & Percent & Total & Percent & $\begin{array}{c}\text { Average } \\
\text { family }\end{array}$ & Sex ratio \\
\cline { 2 - 7 } 1 & 636 & 54.08 & 540 & 45.92 & 1176 & 10.45 & 5.82 & 117.78 \\
2 & 591 & 55.03 & 483 & 44.97 & 1074 & 9.54 & 5.71 & 122.36 \\
3 & 471 & 48.36 & 503 & 51.64 & 974 & 8.66 & 6.13 & 93.64 \\
4 & 879 & 51.74 & 820 & 48.26 & 1699 & 15.10 & 7.08 & 107.20 \\
5 & 1051 & 52.79 & 940 & 47.21 & 1991 & 17.69 & 5.98 & 111.81 \\
6 & 1776 & 52.87 & 1583 & 47.13 & 3359 & 29.85 & 5.60 & 112.19 \\
7 & 503 & 51.33 & 477 & 48.67 & 980 & 8.71 & 5.73 & 105.45 \\
Total & 5907 & 52.49 & 5346 & 47.51 & 11,253 & 100.00 & 6.01 & 110.06 \\
\hline
\end{tabular}

Source: Himali Gaunpalika Bastugat Bibaran, 2019. 
Table 4. Ward wise distribution of population and population density.

\begin{tabular}{cccc}
\hline Ward No. & Area $($ Sq.Km) & Population & Density \\
\hline 1 & 130.48 & 1176 & 9.01 \\
2 & 80.08 & 1074 & 13.41 \\
3 & 486.85 & 974 & 2.00 \\
4 & 24.63 & 1699 & 68.98 \\
5 & 49.73 & 1991 & 40.04 \\
6 & 32.75 & 3359 & 102.56 \\
7 & 25.82 & 980 & 37.96 \\
Total & 830.34 & 11,253 & 39.14 \\
\hline
\end{tabular}

Source: CBS, 2011.

Table 5. Population distribution by age in Himali Gaunpalika.

\begin{tabular}{|c|c|c|c|c|c|c|c|c|c|c|}
\hline \multirow[b]{2}{*}{ Ward no } & \multicolumn{8}{|c|}{ Age in the year } & \multirow[b]{2}{*}{ Total } & \multirow[b]{2}{*}{ Percent } \\
\hline & $\begin{array}{l}0-5 \\
\text { yrs. }\end{array}$ & $\begin{array}{c}6-14 \\
\text { yrs. }\end{array}$ & $\begin{array}{c}15-18 \\
\text { yrs. }\end{array}$ & $\begin{array}{c}19-24 \\
\text { yrs. }\end{array}$ & $\begin{array}{c}25-49 \\
\text { yrs. }\end{array}$ & $\begin{array}{c}50-596 \\
\text { yrs. }\end{array}$ & $\begin{array}{c}60-69 \\
\text { yrs. }\end{array}$ & $\begin{array}{l}70 \text { yrs } \\
\text { above }\end{array}$ & & \\
\hline 1 & 165 & 271 & 115 & 338 & 127 & 69 & 60 & 31 & 1176 & 10.45 \\
\hline 2 & 180 & 241 & 90 & 302 & 103 & 51 & 62 & 45 & 1074 & 9.54 \\
\hline 3 & 158 & 232 & 85 & 309 & 67 & 47 & 40 & 36 & 974 & 8.66 \\
\hline 4 & 277 & 358 & 154 & 487 & 188 & 110 & 75 & 50 & 1699 & 15.10 \\
\hline 5 & 301 & 462 & 207 & 496 & 239 & 131 & 79 & 76 & 1991 & 17.69 \\
\hline 6 & 409 & 814 & 370 & 903 & 390 & 195 & 150 & 128 & 3359 & 29.85 \\
\hline 7 & 98 & 197 & 101 & 283 & 133 & 53 & 75 & 40 & 980 & 8.71 \\
\hline Total & 1588 & 2575 & 1122 & 3118 & 1247 & 656 & 541 & 406 & 11253 & 100.00 \\
\hline Percent & 14.11 & 22.88 & 9.97 & 27.71 & 11.08 & 5.83 & 4.81 & 3.61 & 100.00 & \\
\hline
\end{tabular}

Source: Himali Gaunpalika Bastugat Bibaran, 2019.

Table 5 shows that about 54.59 percent populations fall under 15 - 59 years age group followed by 6 - 14 years age group, which is 22.88 percent. Age group between below 5 years population occupies third position, which percent is 14.11. Nominal percentage of population (8.42\%) falls under age group between above 60 years. Economically active age population is 54.59 percent.

\subsubsection{Economic Settings}

Economy is one of the most important components of human to make their lives better. There are different sources of income of people in the Gaunpalika. Major income sources include Agriculture, services in government and non-government agencies, business, labor work, and livestock.

\subsubsection{Remittances}

Youths have been going to India as a seasonal labor since long decades. India is 
the main destination of international labour migration. Gulf countries, Malaysia, Korea, and Japan are become new destination countries in the recent years. Table 6 shows the destinations countries of international labour migration.

Table 6 shows that out of the total international migrants, majority youths (49.9\%) are migrated to Golf countries as wageworker. Gulf countries are opened as new destination and India as our traditional foreign employment hub, where 48.32 percent youth migrated as laborer.

\subsubsection{Sources of Income}

Household income of the Gaunpalika largely depends on remittance, services-pension, agriculture, business, and wage labor. Despite the dominance of agriculture, its contribution in household economy is less. Remittance is the main source of income of the Gaunpalika (Table 7).

Table 6. Destination countries of international labour migration of Himali.

\begin{tabular}{|c|c|c|c|c|c|}
\hline \multirow[b]{2}{*}{ Ward no. } & \multicolumn{4}{|c|}{ Destination countries of international migration } & \multirow[t]{2}{*}{ Total } \\
\hline & India & $\begin{array}{c}\text { Gulf } \\
\text { countries }\end{array}$ & $\begin{array}{c}\text { Europe, } \\
\text { America, Australia }\end{array}$ & Japan and Korea & \\
\hline 1 & 60 & 45 & - & - & 105 \\
\hline 2 & 36 & 30 & - & - & 66 \\
\hline 3 & 23 & 20 & - & - & 43 \\
\hline 4 & 21 & 32 & - & 2 & 55 \\
\hline 5 & 11 & 24 & - & - & 35 \\
\hline 6 & 39 & 42 & - & 2 & 83 \\
\hline 7 & 13 & 17 & 1 & 3 & 34 \\
\hline Total & 203 & 210 & 1 & 7 & 421 \\
\hline Percent & 48.32 & 49.9 & 0.002 & 1.7 & 99.9 \\
\hline
\end{tabular}

Source: Himali Gaunpalika Bastugat Bibaran, 2019.

Table 7. Sources of income.

\begin{tabular}{ccc}
\hline Income Sources & Income per annum (NRs. '000) & Percent \\
\hline Remittance & 138,000 & 47.26 \\
Service/Pension & 52,300 & 17.91 \\
Agriculture \& Livestock & 51,800 & 17.74 \\
Business & 43,750 & 14.98 \\
Labor works & 6150 & 2.10 \\
Total & 292,000 & 100.00
\end{tabular}

Source: Himali Gaunpalika Bastugat Bibaran, 2019. 


\subsubsection{Employment/Occupation}

Employment status is key indicator of economic status and source of income. Agriculture, foreign employment, business, wage labour and are main occupation and employment sector. Within the Gaunpalika, out of total about 6255 (55.58\%) population is found economically active and rest of the $44.42 \%$ population is dependent economically on rest of the family member. The majority of people are involved in agriculture while a few people are involved in business. Out of the total economic active age population, 74.38 percent are involved in agricultural sector. Table 8 shows the population distribution by occupation status in Himali Gaunpalika.

Table 8 shows that notable percentage of people is engaged in foreign employment, which is second main sector of employment in Gaunpalika. Service comprises third position as occupation of people. Business and wage labour are other sectors of employment. Business includes small hotel, restaurant, teashops, cloth shops, shoes shop, Beauty Parlor etc.

\subsubsection{Health Status}

Health status depends on nutrition, sanitation, health service etc. it is reported that diarrhea, common cold, scabies, dysentery, gastric, fevers, tonsil, pneumonia are the most common diseases. Cancer, heart diseases are the major diseases. Large share of people go to health post after not cure by traditional treatment. Some people directly go to hospital for treatment in the case of suffering from hard diseases. It is also found that most of pregnant women visit to health post, but common practice in home based delivery. Only, in critical condition, pregnant women go to hospital. People call ambulance and go to Bayalpata hospital or Dhangadhi hospital. Table 9 shows the details of health services in Gaunpalika.

Table 9 shows that there are 2 health posts and 1 Samudayik Swasthya Kendra. The basic services available at these Health Center are Vaccination, basic health examination, family planning etc. Health post also provides services like Vaccination, basic health examination, family planning, safe motherhood.

According to Himali Gaunpalika Bastugat Bibaran, 2019, 235 children were vaccinated against BCG, 81 children were vaccinated against Pentavalent vaccine (protection to a child from 5 life-threatening diseases-Diphtheria, Pertussis, Tetanus, Hepatitis B and HIV), 228 children took Polio, Dadura Rubela and 254 children were vaccinated against Japanese encephalitis in this Gaunpalika. There is found that 15 children are malnutrition.

It was found that programs related to family planning and different institutions in the Gaunpalika in the past conducted birth control. Both men and women had taken birth control measures for family planning. According to Himali Gaunpalika Bastugat Bibaran 2075, 427 women used temporary family planning means, whereas 349 men used temporary family planning devices. The status of household health depends on the toilet facility and sanitation. It is reported that Himali Gaunpalika was declared Open Defection Free (ODF). 
Table 8. Occupation status in Himali Gaunpalika.

\begin{tabular}{ccc}
\hline Types & & Percent \\
\hline Agriculture & 4653 & 74.38 \\
Foreign employment & 421 & 6.73 \\
Services (Government and Private) & 285 & 4.55 \\
Student & 339 & 5.41 \\
Business & 215 & 3.43 \\
Wage Labour & 61 & 0.97 \\
Housewife & 281 & 4.49 \\
Total & 6255 & 100.00 \\
\hline
\end{tabular}

Source: Himali Gaunpalika Bastugat Bibaran, 2019.

Table 9. Distribution of health institution in Himali Gaunpalika.

\begin{tabular}{ccccccc}
\hline Name & $\begin{array}{c}\text { Ward } \\
\text { no. }\end{array}$ & Staff & $\begin{array}{c}\text { Birthing } \\
\text { service }\end{array}$ & Clinic & $\begin{array}{c}\text { Family } \\
\text { Planning }\end{array}$ & $\begin{array}{c}\text { Vaccinate } \\
\text { service }\end{array}$ \\
\hline Bichchhya Health Post & 1 & 4 & Yes & Yes & Yes & Yes \\
Rugin Health Post & 5 & 4 & Yes & yes. & Yes & Yes \\
Samudayik Swasthya Kendra Dhim & 6 & 2 & Yes & - & Yes & Yes \\
\hline
\end{tabular}

Source: Himali Gaunpalika Bastugat Bibaran, 2019.

Discussing anthropological differences between contraception and natural family planning raises questions not usually asked in comparing what can at first sight simply appear to be two approaches toward the same end (birth control). These questions invite a re-contextualization of the entire discussion within much more inclusive concerns for the complete human person, male and female, and their sexual relationship to each other. In most areas of personal health, many individuals rightly call for medicinal or surgical approaches to health care that are more holistic and natural and less intrusive, and they also actively support ecological conservation of the world's macro-environment.

The almost universal promotion of contraception rather than of fertility awareness is a puzzling anomaly in view of the use of holistic and ecological principles in other health and environmental concerns. In case of couple living together, there are many family planning devices available. Among them; modern methods and traditional methods are mostly common. In traditional methods drop out is one of the important methods, while in case of couple who live separate in the course of work they do not need any contraceptive means to use to control the birth. Here I would like to raise the fact that emergency contraceptive pills and condoms are widely used in study area. The population of 5021, are of the age between 19 - 59 which comprise $44.61 \%$ of total population mostly the probable age who use any methods of contraceptives.

Table 10 shows that the trends on women using contraceptives, those women 
whose husbands are away from them usually do not use any contraceptives, but in case of emergency they use emergency pills, when they are in extra-marital relationship. In case of their extra marital relations they compelled the partners to use condom compulsory that's why the demands of condom in study are is high.

Average family size (people per family) is calculated by dividing the population living in family by total households. Average household size can also be a reflection of personal or cultural preferences or economic choices. Persons per family who share common kitchen or average family size, is obtained by dividing the number of persons in family by the number of households. It is found that the average household size of Himali Gaupalika is 6.01, which is higher than the national average (4.88). Household size ranges from 5.60 in ward no. 6 to 7.08 in ward no. 4 (Table 11).

Table 10. Use of contraceptives among respondent whose partner is elsewhere in Himali Gaunpalika.

\begin{tabular}{|c|c|c|c|c|c|}
\hline \multirow{2}{*}{ Ward no } & \multicolumn{3}{|c|}{ Destination countries } & \multicolumn{2}{|l|}{ Status of contraceptive users } \\
\hline & India & Abroad & Total & Users & Non-users \\
\hline 1 & 60 & 45 & 105 & $\begin{array}{l}\text { Mostly uses short term } \\
\text { facilities that are available } \\
\text { such as condom, emergenc } \\
\text { pills etc. As per their needs. }\end{array}$ & $\begin{array}{l}\text { Mostly they do not use while } \\
\text { their partners are away from } \\
\text { home but due to the extra } \\
\text { ymarital relation they use } \\
\text { emergency pills when they } \\
\text { need. }\end{array}$ \\
\hline 2 & 36 & 30 & 66 & Not available & $\begin{array}{l}\text { Mostly they do not use while } \\
\text { their partners are away from } \\
\text { home but due to the extra } \\
\text { marital relation they use } \\
\text { emergency pills when they } \\
\text { need. }\end{array}$ \\
\hline 3 & 23 & 20 & 43 & Not available & Not available \\
\hline 4 & 21 & 34 & 55 & Not available & Not available \\
\hline 5 & 11 & 24 & 35 & $\begin{array}{l}\text { Mostly uses short term } \\
\text { facilities that are available } \\
\text { such as condom, emergenc } \\
\text { pills etc. As per their needs. }\end{array}$ & $\begin{array}{l}\text { Mostly they do not use while } \\
\text { their partners are away from } \\
\text { home but due to the extra } \\
\text { ymarital relation they use } \\
\text { emergency pills when they } \\
\text { need. }\end{array}$ \\
\hline 6 & 39 & 44 & 83 & $\begin{array}{l}\text { Mostly uses short term } \\
\text { facilities that are available } \\
\text { such as condom, emergenc } \\
\text { pills etc. As per their needs. }\end{array}$ & $\begin{array}{l}\text { Mostly they do not use while } \\
\text { their partners are away from } \\
\text { home but due to the extra } \\
\text { ymarital relation they use } \\
\text { emergency pills when they } \\
\text { need. }\end{array}$ \\
\hline 7 & 13 & 21 & 34 & Not available & Not available \\
\hline Total & 203 & 210 & 421 & & \\
\hline
\end{tabular}

Source: Himali Gaunpalika Bastugat Bibaran, 2019. 
Table 11. Average family size in Himali Gaunpalika.

\begin{tabular}{ccc}
\hline Ward no & Total population & Average Family sixe \\
\hline 1 & 1176 & 5.82 \\
2 & 1074 & 5.71 \\
3 & 974 & 6.13 \\
4 & 1699 & 7.08 \\
5 & 1991 & 5.98 \\
6 & 3359 & 5.60 \\
7 & 980 & 5.73 \\
Total & 11,253 & 6.01 \\
\hline
\end{tabular}

Source: CBS, 2011.

\subsubsection{Male Migration and Contraceptive Using Pattern}

South Asia, young married women often face cultural expectations and social pressure to "prove" their childbearing abilities to their families and their husband's families immediately after the marriage (Mensch, Bruce, \& Greene, 1998; Pachauri, 1996). As a result, few married adolescents use contraception. Conversely, sexually active young unmarried women have strong motivation to avoid pregnancy, and so they tend to use contraception (McCauley \& Salter, 1995). It has also been documented that when many young adolescents know about contraceptives, few use them because it is more difficult for adolescents to obtain contraceptives than it is for older, married couples. Often times, adolescents do not know where to go or what to expect.

In study area, it is very difficult to identify and gather the date and information about family planning and contraceptive users among those women whose husbands were migrated abroad or in India for work because if they talk about it to the others society may charge them for their immoral characters. Despite these, some remarkable situations were observed as; there was no substantial change in the use of family planning among women whose husbands were living elsewhere for less than one year. But there was a substantial increase in use of any method and use of modern methods among women whose husbands were living elsewhere for one year or more. However, there was no change in use of modern methods but a substantial increase in use of traditional methods. There was no substantial change in the use of family planning among women whose husbands were living elsewhere for less than one year. Information on current use of contraception among women living together with their husbands or whose husbands are absent can help programs identify and better serve the family planning needs of different groups.

Among couples staying together, there was an increase in use of withdrawal, and an increase in use of the pill, use of IUDs increased slightly among couples staying together, and use of implants increased. 


\subsection{Cultural and Individual Interface}

With the adaptation perspective, it is necessary to consider about the primary determining factor of household process such as production, consumption and reproduction. It was clearly found that Himali Gaupalika's subsistence economy is geared to extracting resources from a bounded local environment, within which migration stranded as major strategies to sustain their life except agriculture and cattle raising.

Under cultural and individual interface, various cultural and social events, phenomena and processes were done; beginning from the birth and childhood (process of birth rituals, naming etc.), marriage (procedure of marriage ceremonies), then death (death ritual). Similarly, annual cultural calendars and their celebrations were also comprises here because they are important and responsible factors for the adaptation of Himali Gaupalika indirectly.. but importantly, the migration of males supports the Himali Gaupalika's adaptation in two ways; firstly, remittance help to cope the food scarcity, and satisfactions of their others domestic subsistence based needs (food, shelter, cloths, health, educations etc.); and secondly, it also helps to maintain the population balance, their household composition by creating the fertility gap without using contraceptives.

\subsection{Anthropological Lens}

It is found that the existing situation of Himali Gaupalika identifies the five main ecological constraints on fertility decreases. They are 1) natural resources availability, 2) flora and fauna, 3) subsistence economic and technology, 4) topography, 5) health and population, and 6) social settings. It is found that how these factors determine the fertility decrease without increase in contraceptives of Himali Gaupalika so as to perverse their subsistence or livelihood. Their economic strategies such as agriculture, herding, technology, trade, population etc. are determined by the environmental condition of the study area, which is the central analysis of this paper.

Similarly, the five components of the ecosystems-1) economic strategy, 2) population pattern, 3) technology, 4) social organization cum institution and 5) environmental conditions-are directly interrelated affecting each other primarily. The factors such as culture and religion, conflict, disease, food scarcity (in populist term-famine) etc. also influence these five components secondarily. In this article, researcher not only concentrate on identifying the natural or ecological constraints of decreasing fertility of human and nature i.e. soil, but suggests and recommends how to attain the maintain equilibrium by out sourcing from the earning from migration in India and gulf and in abroad. In broader sense,

The fertility issues of Himali Gaupalika, including use of contraceptive shows unique nature especially; in married women with migrant husbands reflect a quite different, unique and interesting. Usually women were found eager to pregnant after their husbands' arrival in home from destination. Improving healthy communication between women and their migrant husbands prior to home visits may improve relationship quality, but in some case there are pro- 
found conflict and misunderstanding among them even if they went separate after arrival of her husband in Himali Gaupalika of Bajura district of Nepal.

But in Nepal, where nearly one-third of women of reproductive age are separated from their husbands, many do not use family planning methods on a regular basis because-except in the case of extramarital sex-they are not at immediate risk of pregnancy. Women whose husbands are away still have a need for contraceptives upon their husbands' return, but it is observed, that women's emphasis might be on using emergency contraception and barrier methods, reflecting that they might be sexually active for short periods of time when their husbands visit at home or in extra marital relations of Himali Gaupalika of Bajura district in Nepal.

Contraceptive use did not appear to have any major effect in the decline in fertility in Himali Gaupalika of Bajura district of Nepal, while postpartum insusceptibility contributed to an increase in fertility. Climatic factors are also responsible for the fertility increases or decreases. In case of Himali Gaupalika ecological, food habit, geography, heavy work load of work etc play an important role in fertility.

Based on the studied carried in Himali Gaupalika, population is examined as a dependent variable and its expression is determined by the interaction of biological and social factors for their adaptation. Himali Gaupalika is a naturally fertile in population and ecologically enriched. Generally, people of Himali Gaupali, do not use contraceptives as a practice of birth control and the general feeling is that such practices are not going to be adapted even in future, because, their couples usually do not live together almost all time. Usually, male are migrated for searching opportunity in cities of countries like Dhangadhi, Nepalgunj, Kathmandu etc. and out from the countries too; mostly in India or in gulf countries. It is found that, their reproductive physiology depends on various functions of behaviors including their work loads, nutrition compositions, mental health, availability of partner and various environment factors too. The close relationships between physiological and behavioral components are the keenly responsible for their fertility. Similarly, fertility of Himali Gaupalika depends on its interrelationship between biotic factors flora-fauna including human and abiotic factors-available of climatic conditions, environmental resources etc. and their reciprocal relationship ultimately determinew the adaptation of Himali Gaupalika population. Both human and soil fertility are found decreasing without intervention of any technology.

\section{Summary and Conclusion}

It is found from the study carried out in Himali Gupalika that populations are the determinant variables for the adaptation of Himali Gaupalika, population is examined as a dependent variable and its expression is determined by the interaction of biological and social factors. Himali Gaupalika, is a naturally fertile in population and people of study area usually practice no birth control by using 
contraceptives and artificial methods. They have had and they will practice natural methods that are migration of male for a long time to work in any place, and the general feeling is that such practices are not going to be adapted even in future.

In another hand, fertility is not only determined by the demographic factors only, rather than it is highly determined by ecological one. Ecological factors like climate, topography, availability of natural resources, technology adopted, including socio-natural systems are the main determining factors. So, it is a complex one which should be studied by using multidisciplinary approach. In this study, fertility was determined by ecological factor rather than contraceptive use. Fertility is directly related to migration. Fertility in Nepal is determined by migration which is one of the key factors and migration determines whether fertility increases or decreases. Children get high value because they help in household task frees their mothers and family members in domestic tasks. Even they help sometimes in farms and it also helps to free mother and other family members form their overloaded works in both household and in farm. Although fertility has been decreasing in Nepal since 1981, it is still high compared to many other developing countries because Nepal still follows at least two children in a family while in some other countries single child is mandatory.

Besides these, cultural factors are also playing a determining role in what should be the population dynamics especially fertility. Migration and fertility are interrelated and reciprocal causal factors in the case of Himali Gaupalika. One determines another-when population increases while increasing fertility, there is no enough subsistence then they should migrate for their mere subsistence, and on the other hand, increasing trend of migration will decrease the fertility but secure the food and it makes their adaptation very easy. That's why they have practiced the migration for their adaptation strategy without using contraceptives.

Despite all factors like increasing age at marriage, increasing knowledge about contraceptives uses, increasing socio-economic levels of people, increasing access towards contraceptives, etc., migration is one of the main factors to determine fertility in Nepal. Generally, increasing migration trends must decrease the use of contraceptives but in the case of Nepal both are increasing nowadays. It is a great concern in Nepal in general and Himali Gaupalika in particular. Here it is found that, male migration towards abroad and even India, geography, climate (cold climate), heavy workload due to difficult geography, food habit (mainly carbohydrate sufficiency rather than protein based) etc are playing a key role for decreasing fertility rather than using contraceptives.

\section{Conflicts of Interest}

The author declares no conflicts of interest regarding the publication of this paper.

\section{References}

Adhikari, J., \& Seddon, D. (2002). Pokhara: Biography of a Town. Kathmandu: Mandala 
Book Point.

Ali, S. (2007). Go West Young Man: The Culture of Migration among Muslims in Hyderabad, India. Journal of Ethnic and Migration Studies, 33, 37-58. https://doi.org/10.1080/13691830601043489

Bohra, P., \& Massey, D. S. (2009). Processes of Internal and International Migration from Chitwan, Nepal. International Migration Review, 43, 621-651. https://doi.org/10.1111/j.1747-7379.2009.00779.x

Caldwell, J. C. (1976). Toward a Restatement of Demographic Transition Theory. Population and Development Review, 2, 321-366. https://doi.org/10.2307/1971615

CBS (2004). Nepal Living Standard Survey 2003/04, Statistical Report. Kathmandu: National Planning Commission, HMG Nepal.

CBS (2011). Nepal Census 2011 District Profiles (Demography). Kathmandu: Ministry of Health and Population.

Chen, F., Liu, H., Vikram, K. et al. (2015). For Better or WORSE: The Health Implications of Marriage Separation Due to Migration in Rural China. Demography, 52, 1321-1343. https://doi.org/10.1007/s13524-015-0399-9

DoFE (2014). Labour Migration for Employment. A Status Report for Nepal: 2013-2014, Government of Nepal. Kathmandu, Nepal: Ministry of Labor and Employment.

DoFE (2018). Labour Migration for Employment A Status Report for Nepal: 2015/20162016/2017, Government of Nepal. Kathmandu: Nepal Ministry of Labor and Employment.

Fricke, T. E. (1986). Himalayan Households; Tamang Demography and Social Processes. Ann Arbor, MI: UMI Research Press.

Gao, Y., Li, L. P., Kim J. H. et al. (2010). The Impact of Parental Migration on Health Status and Health Behaviors among Left behind Adolescent School Children in China, BMC Public Health, 10, 56. https://doi.org/10.1186/1471-2458-10-56

Hagen, T., \& Kizaki, K. (1994). Report on the Geological Survey of Nepal. Volume 1: Preliminary Reconnaissance. Denkschriften Schweizerische Naturwissenschaften Gesellschaft, Bd, 86, 1-185.

Himali, G. (2019). Himali Gaunpalika Bastugat Bibran, 2019.

Hollema, S., Pahari, K., Regmi, P., \& Adhikari, P. (2008). Passage to India: Migration as a Coping Strategy in Times of Crisis in Nepal. Kathmandu.

Howell, N. R. (2000). A Feminist Cosmology: Ecology, Solidarity, and Metaphysics. New York: Humanity Books.

Karki, Y. B. (1992). Sex Ratio in Nepal. Economic Journal of Nepal, 15, 30-37. https://doi.org/10.3126/jcmsn.v15i1.20753

Kaspar, H. (2006). Gender and Sustainable Development: Case Studies from NCCR North-South.

Khanal, N. R., \& Watanabe, T. (2006). Abandonment of Agricultural Land and Its Consequences: A Case Study in the Sikles Area, Gandaki Basin, Nepal Himalaya. Mountain Research and Development, 26, 32-40. https://doi.org/10.1659/0276-4741(2006)026[0032:AOALAI]2.0.CO;2

Levitt, P. (1998). Social Remittances: Migration Driven Local-Level Forms of Cultural Diffusion. International Migration Review, 32, 926-948.

https://doi.org/10.1177/019791839803200404

Lu, Y. (2012). Household Migration, Social Support, and Psychosocial Health: The Perspective from Migrant-Sending Areas. Social Science \& Medicine, 74, 135-142. 
https://doi.org/10.1016/j.socscimed.2011.10.020

Massey, D. S., Arango, J., Hugo, G., Kouachi, A., Pellegrino, A., \& Taylor, J. E. (1993). Theories of International Migration: A Review and Appraisal. Population and Development Review, 19, 431-466. https://doi.org/10.2307/2938462

McCauley, A. P., \& Salter, C. (1995). Meeting the Needs of Young Adults. Population Reports. Series J, 41, 1-43.

Mensch, B. S., Bruce, J., \& Greene, M. E. (1998). The Uncharted Passage Girls' Adolescence in the Developing World. New York: Population Council.

Milton, K. (1997). Ecologies: Anthropology, Culture and the Environment. International Social Sciences Journal, 49, 477-495. https://doi.org/10.1111/j.1468-2451.1997.tb00039.x

Morooka, H., \& Liang, Z. (2009). International Migration and the Education of Left-Behind Children in Fujian, China. Asian and Pacific Migration Journal, 18, 345-370. https://doi.org/10.1177/011719680901800302

NDHS (2011). Nepal Demographic and Health Survey 2011. Kathmandu, Nepal: Ministry of Health and Population.

NDHS (2016). Nepal Demographic and Health Survey 2016. Kathmandu, Nepal: Ministry of Health and Population.

NFHP II (2012). National Family Health Program Survey. Kathmandu, Nepal.

Pachauri, S. (1996). Shift from Family Planning to Reproductive Health New Challenges, In K. Srinivasan (Ed.), Population Policies and Reproductive Health. New Delhi: Population Foundation of India, Hindustan Publishing Corporation (India).

Roy, A., \& Nangia, P. (2005). Impact of Male out-Migration on Health Status of Left behind Wives: A Study of Bihar, India. Tours, France: International Union for the Scientific Study of Population XXV International Population Conference.

Schmeer, K. (2009). Father Absence Due to Migration and Child Illness in Rural Mexico. Social Science \& Medicine, 69, 1281-1286. https://doi.org/10.1016/j.socscimed.2009.07.030

Seddon, D., Adhikari, J., \& Gurunga, G. (2001). The New Lahures: Foreign Employment and Remittance Economy of Nepal. Kathmandu: Nepal Institute of Development Studies.

Sevoyan, A., \& Agadjanian, V. (2010). Male Migration, Women Left behind, and Sexually Transmitted Diseases in Armenia. International Migration Review, 44, 354-375. https://doi.org/10.1111/j.1747-7379.2010.00809.x

Sinha, A. C. (2009). Introduction. In T. B. Subba, \& A. C. Sinha (Eds.), Indian Nepalis. Issues and Perspectives. New Delhi: Concept Publishing Company.

Skeldon, R. (2008). Linkages between Internal and International Migration. In J. deWind, \& J. Holdaway (Eds.), Migration and Development within and across Borders: Research and Policy Perspectives on Internal and International Migration (pp. 29-38). New York: IOM.

Skledon, R. (2009). Of Skilled Migration, Brain Drains and Policy Responses. International Migration, 47, 3-29. https://doi.org/10.1111/j.1468-2435.2008.00484.x

Stöcklin J. (1980). Geology of Nepal and Its Regional Frame. Journal of the Geological Society, 137, 1-34. https://doi.org/10.1144/gsigs.137.1.0001

Taylor, J. (2006). International Migration and Economic Development. In International Symposium on International Migration and Development. Turin: UN.

Thieme, S. (2006). Social Networks and Migration: Far West Nepalese Labour Migrants 
in Delhi: NCCR NorthSouth Dialogue, NCCR North-South. Berne.

Webber, G., Spitzer, D., Somrongthong, R. et al. (2012). Facilitators and Barriers to Accessing Reproductive Health Care for Migrant Beer Promoters in Cambodia, Laos, Thailand and Vietnam: A Mixed Methods Study. Global Health, 8, 21.

https://doi.org/10.1186/1744-8603-8-21 